DOI 10.4467/2543733XSSB.17.023.8321

KRZYSZTOF KRYSIENIEL

Wydział Zamiejscowy w Chorzowie

Wyższej Szkoły Bankowej w Poznaniu

\title{
GDY WSPÓLNY (?) JĘZYK DZIELI... POLITYCZNE I PRAWNE SKUTKI ROZPADU JEZZYKA SERBSKO-CHORWACKIEGO (WZGLEDNIE CHORWACKO-SERBSKIEGO)
}

\begin{abstract}
Stranac kojem su rekli da je domaće stanovništvo jezički jako osjetljivo zadesi se negdje u Bosni, gdje nije mogao ustanoviti etničku obojenost jezika kojim se služio konobar. Naručuje kafu. Nema. Pa kavu. Opet nema. Pa kahvu. A konobar mu, iznerviran, odgovori: ma svejedno je kako ćeš je zvati - nema vode! ${ }^{1}$
\end{abstract}

Słowa kluczowe: język serbsko-chorwacki, język serbski, język chorwacki, język bośniacki, dialekty bałkańskie

\section{Wprowadzenie}

Bez wątpienia język serbsko-chorwacki lub chorwacko-serbski był (jest?) swoistym fenomenem filologicznym, gdyż ,(..) dwuczłonowa nazwa łączy języki dwóch odrębnych narodów”2. Współcześnie około 30 milionów ludzi na całym świecie posługuje się kilkoma językami, które powstały w wyniku jego oficjalnego rozpadu. Między nimi nie ma de facto żadnych głębokich różnic fleksyjnych, leksykalnych itp., a stopień wzajemnego zrozumienia jest zdecydowanie wyższy niż np. między Austriakami i Niemcami z północy RFN. Jednak, jak pokazuje obecna sytuacja na obszarze byłej Jugosławii, brak bariery językowej nie zapobiegł długim i krwawym konfliktom. Wprost przeciwnie, powstało kolejne pole konfliktu, tym razem o charakterze lingwistycznym. Każdy naród chciał

${ }^{1}$ D. De dović, Do you speak BCS?, „Status”, 2004, nr 2, s. 79.

${ }^{2}$ B. O c zkow a, Wplyw polityki językowej w Jugosławii na norme języka chorwackiego, „Bulletin de la Société Polonaise de Linguistique”, 2002, LVIII, s. 107.

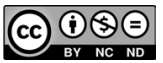


mieć swój własny język, który odróżniałby się od pozostałych, w domyśle gorszych. Stąd przedziwne próby stworzenia nowych standardów przez filologów sympatyzujących z nacjonalistycznie nastawionymi władzami, często oderwanych od tradycji oraz języka, którym posługują się w codziennym życiu mieszkańcy.

Podstawowym celem niniejszego artykułu będzie wykazanie, iż przyczyną tego typu działań jest przede wszystkim polityka, prowadzona przez władze poszczególnych republik, które powstały w wyniku rozpadu Jugosławii, a w których obowiązywał język serbsko-chorwacki (względnie chorwacko-serbski). Doszło w tym przypadku do wyraźnej polityzacji kwestii językowej, gdyż niewielkie różnice językowe zamienione zostały w głębokie podziały polityczne, które z kolei przyczyniły się do zmian o charakterze prawnym.

Przed przystąpieniem do analizy zarysowanej powyżej problematyki, należy jeszcze pokrótce wyjaśnić, dlaczego wybrano wersję nazwy ,język serbsko-chorwacki” (chorwacko-serbski), a nie również spotykane w polskiej literaturze określenie „serbo-chorwacki”. Autor zdecydował się przyjąć to pierwsze rozwiązanie, opierając się na publikacjach licznych uznanych autorów, takich jak B. Oczkowa ${ }^{3}$, M. Okuka ${ }^{4}$, R. Szul ${ }^{5}$ czy J. Rapacka ${ }^{6}$.

Trudno w sposób jednoznaczny zdecydować (ale nie to przecież ma być głównym celem tej pracy), czy omawiając problematykę związaną z językiem serbsko-chorwackim, ma się do czynienia z jednym językiem literackim (standardowym), być może o charakterze policentrycznym, czy też pewną grupą bardzo zbliżonych, ale jednak odmiennych języków. Można zgodzić się z J. Rapacką, że:

mówiąc o wspólnocie językowej, nie mamy na myśli wspólnego języka standardowego, lecz wspólnotę grupy dialektów (diasystemu), wyodrębnionych z grupy południowo-słowiańskiej i nazywanych serbsko-chorwackimi, bądź chorwacko-serbskimi?

Jednocześnie należy brać pod uwagę badania lingwistów, w których przedstawia się liczne dowody na istnienie jednego języka standardowego, w tym niemal 100-procentową zgodność leksykalną w zakresie słownictwa podstawowego i ponad 75-procentową identyczność wszystkich tych cech, które składają się na język (co jest wyższym wynikiem niż przy porównaniu wariantów występujących $w$ języku angielskim, francuskim, niemieckim czy hiszpańskim $)^{8}$.

Trzeba równocześnie podkreślić, że na omawianym w poniższym artykule obszarze występuje bardzo duża liczba dialektów - niektórzy autorzy wskazują ich nawet ponad 20. Stanowią one różne wariacje narzecza kajkawskiego, sztokawskiego, czakawskiego

3 Ibidem, s. 107; B. Oc zk ow a, Zagadnienia sporne w językoznawstwie chorwackim i serbskim po rozpadzie języka serbsko-chorwackiego, [w:] Przemiany w świadomości i kulturze duchowej narodów Jugosławii po 1991 roku, red. J. Kornhauser, Kraków 1999, s. 238.

${ }^{4}$ M. O ku k a, Żegnaj, serbsko-chorwacki!, http://pogranicze.sejny.pl/archiwum/krasnogruda/pismo/7/peryf/okuka.htm (dostęp 27.04.2011).

${ }^{5}$ R. S zu 1, Język - naród - państwo. Język jako zjawisko polityczne, Warszawa 2009.

${ }^{6}$ J. R a p a ck a, Śródziemnomorze - Europa Środkowa - Bałkany. Studia z literatur poludniowosłowiańskich, Kraków 2002, s. 442.

7 Ibidem, s. 442.

8 S. Kordić, Jezična politika: prosvjećivati ili zamagljivati?, https://bib.irb.hr/datoteka/565627.JEZICNA_POLITIKA.PDF (dostęp 27.09.2016). 
i torlackiego. Kajkawskim i czakawskim posługują się tylko Chorwaci, torlackim tylko Serbowie, a sztokawskim wszyscy mieszkańcy Bośni i Hercegowiny, Czarnogóry oraz zdecydowana większość Serbów i Chorwatów9. Paradoksalnie, faktycznie występujące podziały językowe bardzo często nie pokrywają się z podziałami narodowymi, co tylko zwiększa stopień skomplikowania omawianej poniżej problematyki.

\section{Zarys historii wspólnego języka}

Korzenie wspólnego języka serbsko-chorwackiego związane są z iliryzmem, czyli ruchem kulturalno-politycznym, który w latach 30 . XIX wieku odwoływał się do idei jedności językowej wszystkich Słowian południowych - więc nie tylko Serbów i Chorwatów. Należy w tym miejscu podkreślić, że do XIX wieku języki serbski i chorwacki rozwijały się osobno, „samodzielnie i dwutorowo”, do tego różniły się zasadniczo, co podkreśla J. Kornhauser ${ }^{10}$.

Wprawdzie język iliryjski szybko odszedł w niebyt, to jednak idea wspólnoty językowej doczekała się realizacji. Stało się tak w wyniku działalności jednej z chorwackich szkół filologicznych, która sięgnęła po rozwiązania przyjęte w Serbii w wyniku przeprowadzonej przez Vuka Karadžicia reformy językowej ${ }^{11}$.

Sama nazwa ,język serbsko-chorwacki” (srpskohrvatski) po raz pierwszy użyta została w 1824 roku, a za jej autora uważa się niemieckiego filologa Jakoba Grima. Wkrótce termin ten starał się rozpropagować Słoweniec Jernej Kopitar ${ }^{12}$. Jednak kluczowe znaczenie dla próby utworzenia wspólnego języka miało porozumienie zawarte w Wiedniu w 1850 roku (Bečki književni dogovor). W czasie tego spotkania, w którym wzięli udział literaci reprezentujący różne narody południowosłowiańskie (pięciu Chorwatów, dwóch Serbów i jeden Słoweniec), ustalono, że podstawą wspólnego języka serbsko-chorwackiego stanie się dialekt sztokawski w wersji ijekawskiej, z równoprawną pozycją alfabetu łacińskiego i cyrylicy ${ }^{13}$.

Początkowo powyższa deklaracja nie miała praktycznych konsekwencji, dopiero pod koniec XIX wieku Chorwaci zaczęli realizować jej założenia ${ }^{14}$. Była to decyzja kluczowa, gdyż na obszarze Chorwacji wyraźne było wówczas zróżnicowanie językowe. Jak słusznie podkreśla R. Szul, na terytorium tego państwa „(...) istnieją trzy wyraźnie różne narzecza (o różnicach porównywalnych lub większych niż np. między polskim a czeskim)”"15, czyli wspomniane już sztokawskie, czakawskie i kajkawskie. Co ważne: „Na bazie tych narzeczy w ciągu wieków powstała bogata literatura, a w sprzyjających warunkach

\footnotetext{
${ }^{9}$ S. Halilović, Jezička stvarnost u Bosni i Hercegovini, „Socjolingwistyka”, 2014, XXVIII, s. 122.

${ }_{10} \mathrm{~J}$. K orn h a u s e r, Konflikt kultur, http://pogranicze.sejny.pl/archiwum/krasnogruda/pismo/7/peryf/kornhaus.htm (dostęp 25.07.2011)

${ }^{11}$ B. Oczkowa, Wplyw polityki..., s. 108.

${ }^{12}$ F. M. V. Kara, A. Meth adžović, Standarizacija jezika i stvaranje država u bivšoj Jugoslaviji, „Balkanija”, 2013, nr 4, s. 59.

${ }^{13}$ Ibidem, s. 59.

${ }^{14}$ Szerzej na ten temat zob.: B. Oczkow a, Zagadnienia sporne..., s. 243; E. B arić i inni, Hrvatska gramatika, Zagreb 1997, s. 33.

${ }^{15}$ R. S zu l, Język-naród-państwo..., s. 101.
} 
społeczno-politycznych mogły wykształcić się odrębne standardowe języki literackie""16. Jednak przyjęcie dialektu sztokawskiego zmieniło w znaczący sposób sytuację, spychając pozostałe na margines.

Stosunkowo szybko doszło do naruszenia porozumienia wiedeńskiego, gdyż zdecydowana większość Serbów wybrała odmianę ekawską zamiast ijekawskiej. W późniejszym okresie podejmowano różne działania mające na celu zbliżenie obu wersji, m.in. na krótko przed wybuchem I wojny światowej pewną popularność zdobyła koncepcja wyrzeczenia się przez Serbów cyrylicy na rzecz latinicy, a w zamian Chorwaci mieli przejść na ekawsztinę ${ }^{17}$. Po zakończeniu działań zbrojnych i powstaniu silnie scentralizowanego Królestwa SHS, później przemianowanego na Królestwo Jugosławii, oficjalnie promowano (w tym także w formie artykułu 3 konstytucji z 1921 roku) istnienie jednego wspólnego języka serbsko-chorwacko-słoweńskiego. Dominacja Belgradu spowodowała, że de facto obowiązywała wersja serbska ${ }^{18}$. W kolejnej konstytucji z 1931 roku, przyjętej w wybitnie niedemokratycznych okolicznościach, nie pojawia się nazwa języka, a jedynie wzmianka w art. 57 odnoszącym się do wyboru posłów i senatorów, iż „mówią i piszą w języku narodowym" 19 .

Wspomniana powyżej dominacja serbskiej wersji szczególnie dotyczyła dziedzin kluczowych z punktu widzenia funkcjonowania państwa - szkolnictwa, armii, sądownictwa czy polityki. Sytuacja uległa zmianie dopiero jesienią 1939 roku wraz z powołaniem Banowiny Chorwackiej, w której po części udało się Zagrzebiowi zrealizować własne aspiracje do usamodzielnienia się, także w ramach polityki językowej. Już w następnym roku ukazała się książka P. Guberiny i K. Krsticia pt. Razlike između hrvatskoga i srpskoga jezika, w której - jak pisze B. Oczkowa - „(...) autorzy stwierdzają, że serbsko-chorwacki to język abstrakcyjny i sztuczny, łączący dwa oddzielnie funkcjonujące języki, każdy z własną odrębną strukturą i historią" ${ }^{20}$. Dążenie do podkreślenia różnic między chorwackim a serbskim było szczególnie widoczne w latach 1941-1945, gdy powołano do życia ustaszowskie Niezależne Państwo Chorwackie, którego władze za wszelką cenę chciały pozbyć się serbizmów, przywracając „czysty” język chorwacki.

W tym samym okresie, czyli podczas II wojny światowej, kierownictwo rosnącej w siłę partii komunistycznej ogłosiło, że w przyszłym wspólnym państwie jugosłowiańskim cztery języki - serbski, chorwacki, macedoński i słoweński - otrzymają status urzędowych i równorzędnych na obszarze całego państwa. Kolejnym krokiem w ramach nowej polityki językowej było Porozumienie nowosadzkie (Novosadski dogovor), podpisane w 1954 roku. Już w pierwszym punkcie tego dokumentu podkreślono, że język Serbów, Chorwatów i Czarnogórców jest taki sam, więc w pełni uzasadnione będzie opracowanie jednej standardowej (literackiej) wersji. Niemniej jednak w ramach tego wspólnego języka Porozumienie dopuszczało użycie dwóch wersji - ijekawskiej (po części błędnie utożsamianej z chorwacką) i ekawskiej (serbskiej) oraz dwóch alfabetów - łacińskiego i cyrylicy ${ }^{21}$. Szczytowym osiągnięciem polityki jedności językowej stała się publikacja

\footnotetext{
${ }^{16}$ Ibidem, s. 101.

${ }_{17}$ R. B u gar s k i, Portret jednog jezika, Beograd 2012, s. 25-26.

${ }^{18}$ Ibidem, s. 26.

${ }^{19}$ R. Glu ši c a, Jezička politika u Crnoj Gori, „Riječ. Nova serija”, 2009, nr 1, s. 24.

${ }^{20}$ B. Oczkowa, Wplyw polityki.., s. 109.

${ }^{21}$ F. M. V. Kar a, A. Me tha ď̌ ović, Standarizacija jezika..., s. 60-61.
} 
przed 1960 rokiem wspólnej gramatyki - Macierz Serbska (Matica srpska) opublikowała ją w wersji ekawskiej i cyrylicą, natomiast Macierz Chorwacka (Matica hrvatska) w wersji ijekawskiej i w alfabecie łacińskim ${ }^{22}$.

\section{Konstytucyjne regulacje w zakresie języka/języków w okresie wspólnego państwa}

Osobną kwestią, obok podejścia stricte lingwistycznego, pozostawał problem regulacji polityczno-prawnych, w tym przede wszystkim konstytucyjnych. Patrząc przez pryzmat ustaw zasadniczych, które uchwalono od momentu utworzenia Królestwa SHS aż po ostateczny rozpad Jugosławii, trudno wskazać na ciągłość i kontynuację przepisów w zakresie języka/języków.

Na mocy pierwszej konstytucji z 28 czerwca 1921 roku, językiem oficjalnie obowiązującym był serbsko-chorwacko-słoweński. Takie rozwiązanie miało czysto polityczny charakter, gdyż dominująca wówczas opcja centralistyczna wyraźnie ignorowała istniejące różnice między narodami wymienionymi $\mathrm{w}$ nazwie $\mathrm{w}$ imię propagandowego hasła ,jeden naród - trzy plemiona". Natomiast przyjęta po zakończeniu wojny w styczniu 1946 roku Konstytucja Federacyjnej Ludowej Republiki Jugosławii w ogóle nie wyliczała ani narodów, ani ich języków. Jak pisze B. Oczkowa, ,Języki te wymieniały konstytucje poszczególnych republik, ale tylko odnośnie postępowania sądowego"²3.

Zmiana podejścia nastąpiła w konstytucji federalnej z 7 kwietnia 1963 roku. Wraz z przemianowaniem państwa na Socjalistyczną Federacyjną Republikę Jugosławii, ogłoszono w niej równouprawnienie języków i alfabetów, przy czym z nazwy wymieniono: serbsko-chorwacki względnie chorwacko-serbski, macedoński oraz słoweński. Wspomniana równość językowa nie dotyczyła Jugosłowiańskiej Armii Ludowej (JNA), w której oficjalnie uprzywilejowaną pozycję otrzymał serbsko-chorwacki ${ }^{24}$.

Takie rozwiązanie przetrwało do ostatniej konstytucji socjalistycznej Jugosławii, uchwalonej w 1974 roku, w której ponownie ogłoszono równouprawnienie języków i alfabetów, ale bez odwoływania się do żadnych konkretnych nazw, dokładne regulacje pozostawiając poszczególnym republikom ${ }^{25}$. Warto podkreślić, że $\mathrm{z}$ tego prawa $\mathrm{w}$ dość szczególny sposób skorzystały władze Socjalistycznej Republiki Chorwacji, gdyż w przyjętej w tym samym roku konstytucji republikańskiej przyjęto sformułowanie, iż: „U SR Hrvatskoj u javnoj je upotrebi hrvatski književni jezik - standardni oblik narodnog jezika Hrvata i Srba u Hrvatskoj, koji se naziva hrvatski ili srpski”26. Tym samym - na co zwraca uwagę B. Oczkowa - język chorwacki po raz pierwszy w komunistycznej Jugosławii został potraktowany jako odrębny ${ }^{27}$.

\footnotetext{
22 Ibidem, s. 63.

${ }^{23}$ B. Oczkowa, Wplyw polityki..., s. 109-110.

24 R. Gluš i c a, Jezička politika u Crnoj Gori, s. 25.

25 B. Oczkowa, Wplyw polityki..., s. 111.

${ }^{26}$ R. B u gars ki, Portret jednog jezika, s. 33.

27 B. Oczkowa, Wptyw polityki.., s. 111.
} 


\section{Rozpad wspólnoty językowej}

Wspomniane powyżej specyficzne rozwiązanie, przyjęte przez republikański parlament w Zagrzebiu, było po części pokłosiem wydarzeń, które miały miejsce na przełomie lat 60. i 70. XX w Chorwacji. Wtedy to w obliczu narastającego niezadowolenia Chorwatów z ich pozycji w państwie związkowym, w tym także kwestii językowej, opublikowano na początku 1967 roku, sygnowaną przez liczne instytucje kulturalne i naukowe, deklarację O nazwie i położeniu chorwackiego języka literackiego. Pisano w niej, że wbrew zapowiedziom prowadzenia równościowej polityki językowej, w Jugosławii dominującym językiem stał się serbski, uzyskując nieformalny status państwowego, spychając jednocześnie chorwacki na plan dalszy i ograniczając jego zasięg terytorial$n y^{28}$. Wspomniana deklaracja stała się symbolicznym początkiem wydarzeń nazwanych „Chorwacką Wiosną” (Hrvatsko proljeće), która na kilka lat mocno zaogniła relacje Zagrzebia z władzami centralnymi ${ }^{29}$.

W tym okresie język jako podstawowy element tożsamości kulturowej i etnicznej stał się źródłem napięcia między serbskimi i chorwackimi elitami intelektualnymi. Przedstawiciele tych drugich protestowali przeciwko spychaniu ich tradycji językowej na margines. Wyrazy typowe dla wersji chorwackiej były tępione jako reakcyjne austrohungaryzmy lub przejawy religijno-nacjonalistycznej nietolerancji i separatyzmu, a nawet jako ustaszowskie ${ }^{30}$.

Zawirowania związane z „Chorwacką Wiosną” część badaczy uznaje za początek końca idei wspólnego języka, gdyż znacząca grupa lingwistów po obu stronach skierowała się w stronę nacjonalizmu, gdzie nie było już miejsca na ponadnarodowe projekty. Końcowym etapem tego procesu stały się prawno-polityczne działania zmierzające do wyodrębnienia i potwierdzenia istnienia czterech samodzielnych (?) języków - serbskiego, chorwackiego, bośniackiego i czarnogórskiego ${ }^{31}$.

\section{Kwestia języka w Serbii}

Bardzo ciekawie pod względem prawnym kształtowała się po rozpadzie wspólnoty jugosłowiańskiej kwestia języka w Serbii. W uchwalonej w 1992 roku ustawie zasadniczej Federacyjnej Republiki Jugosławii, składającej się z Serbii i Czarnogóry, za oficjalny uznano język serbski w wersji ekawskiej i ijekawskiej. Status oficjalnego alfabetu otrzymała tylko cyrylica, a ewentualne używanie alfabetu łacińskiego miało zostać uregulowane w ustawie. Co warte podkreślenia, uchwalona rok wcześniej w serbskim parlamencie republikańskim ustawa językowa za urzędowy uznała serbsko-chorwacki, co stanowiło potwierdzenie rozwiązań przyjętych w konstytucji republikańskiej w 1990 roku. W tej formie ustawa niezmieniona pozostała aż do 2010 roku, mimo że uchwalona

${ }_{28}$ M. J. Zacharias, Komunizm - federacja - nacjonalizmy. System władzy w Jugostawii 1943-1991. Powstanie - przeksztatcenie - rozkład, Warszawa 2004, s. 280.

${ }^{29}$ Szerzej na ten temat zob.: M. Tripalo, Hrvatsko proljeće, Zagreb 1990.

${ }^{30}$ B. Oczkowa, Wplyw polityki.., s. 111.

31 F. M. V. Kara, A. Meth a džović, Standarizacija jezika, s. 64. 
w 2006 roku konstytucja Republiki Serbii za język oficjalny uznała serbski (i cyrylicę). Jak łatwo można policzyć, przez blisko dwie dekady (z krótką przerwą) ustawa regulująca problem języka oficjalnego pozostawała ewidentnie w sprzeczności z postanowieniami konstytucyjnymi ${ }^{32}$.

W międzyczasie w 2003 roku zaczął funkcjonować w miejsce Socjalistycznej Federacyjnej Republiki Jugosławii specyficzny twór ponadpaństwowy, czyli Serbia i Czarnogóra. W uchwalonej rok wcześniej Karcie Konstytucyjnej nie uregulowano jednak problemu języka urzędowego.

W pewnym sensie „ofiarą” rozpadu wspólnoty językowej w Serbii stał się alfabet łaciński. Na początku lat 90. XX wieku dominująca wówczas ideologia nacjonalistyczna znalazła w nim swoiście rozumianego wroga, gdyż używano go w krajach uznawanych przez Belgrad za szczególnie zaangażowane w osłabianie pozycji Serbii w Europie (Watykan, RFN, a przede wszystkim Chorwacja). Tym samym na wszelkie możliwe sposoby promowano cyrylicę, a alfabet łaciński wypchnięto na margines ${ }^{33}$.

\section{Kwestia języka w Chorwacji}

Oficjalnie status państwowego język chorwacki (razem z alfabetem łacińskim) otrzymał na mocy konstytucji Republiki Chorwacji z 22 grudnia 1990 roku, przy czym należy pamiętać, że nie od razu weszła ona w życie. Mimo silnej presji organów władzy państwowej na przestrzeganie swoistego puryzmu językowego (specyficzna polityka w tym zakresie pierwszego prezydenta Franjo Tuđmana jest tego najlepszym dowodem ${ }^{34}$ ), nie udało się w kolejnych latach przyjąć odpowiednich aktów prawnych, w tym przede wszystkim ustawy, która regulowałaby status i formę języka chorwackiego ${ }^{35}$.

W Republice Chorwacji duży nacisk o charakterze politycznym kładzie się na promocję „czystej” wersji języka ojczystego. Powołano w tym celu szereg różnych instytucji, jak np. Institut za hrvatski jezik i jezikoslovlje (utworzony w 1997 roku) czy też Vijeće za normu hrvatskoga standardnog jezika (działającą w latach 2005-2012) ${ }^{36}$. Czasopismo naukowe „Jezik” od 1993 roku corocznie przeprowadza konkurs, do którego można zgłaszać nowe wyrazy, mające być odpowiednikiem dotychczas używanych, a uważanych za niedostatecznie chorwackie. Takie nagrody przyznano za nowe wersje m.in. „dowodu osobistego” (osobnica, poprzednio lična karta), „,emotikonu” (osjećajnik) czy „leżącego żandarma" (uspornik, kiedyś ležeci policajac) ${ }^{37}$.

Równie interesująco, z punktu widzenia dążenia chorwackich władz do podkreślenia odrębności językowej, kształtują się relacje Zagrzebia z instytucjami Unii Europejskiej.

${ }^{32}$ R. Bugars ki, Portret jednog jezika, s. 34-35; M. Grč e vić, Suvremena jezična situacija u slavenskim zemljama, [w:] Slavenski jezici u usporedbi z hrvatskim, red. D. Sesar, Zagreb 2011, s. 148.

${ }_{33}$ R. Bugars ki, Portret jednog jezika, s. 53.

${ }^{34}$ Szerzej na ten temat zob.: K. Kry si en i e 1, Język w stużbie polityki-przypadek współczesnej Chorwacji, [w:] Stowianie w Europie. Historia. Kultura. Język, red. K. Pietrzycka-Bohosiewicz, A. Wawrzyńczak, B. Gołąbek, Kraków 2008.

35 B. B or i ć, Nova država - nova jezična politika, „Kroatologija”, 2014, nr 1, s. 27.

${ }^{36}$ J. Granić, Hrvatski kao 24. službeni jezik Europske unije, „Zbornik radova Filozovskog fakulteta u Splitu”, 2012, nr 5, s. 335.

${ }^{37}$ R. Bugars ki, Portret jednog jezika, s. 45. 
Klarowna sytuacja zachodzi, gdy przyjeżdża delegacja unijna do Chorwacji, gdyż obsługę translatorską zapewnia strona chorwacka i są to thumacze posługujący się „,zystym” chorwackim. Natomiast w razie wizyt delegacji chorwackich w instytucjach unijnych zapewnienie thumaczenia jest obowiązkiem danej instytucji. W tym przypadku nie musi to być Chorwat, a może być np. Bośniak lub Serb pracujący w Brukseli, gdyż - jak pisze J. Hlavač - ,(...) thumacze nie są zatrudniani według kryterium etnicznego, ale w oparciu o umiejętności lingwistyczne"38.

Symboliczne wydarzenie, stanowiące w pewnym sensie podsumowanie oficjalnego rozpadu wspólnoty językowej, miało miejsce 1 września 2000 roku. W tym dniu język chorwacki został wpisany jako osobny język do rejestru międzynarodowej klasyfikacji bibliotekarskiej jako ISO 639-2 ${ }^{39}$.

\section{Kwestia języka w Bośni i Hercegowinie}

Pierwsze prawne rozstrzygnięcia dotyczące nazwy języka obowiązującego na obszarze Bośni i Hercegowiny zapadły na przełomie XIX i XX wieku, pod okupacją austro-węgierską. Serbscy i chorwaccy mieszkańcy tej prowincji uzyskali w ograniczonym zakresie możliwość nazywania języka, którym się posługiwali, mianem serbskiego lub chorwackiego. Jednocześnie nowe władze podjęły próbę - nieudaną, jak się miało szybko okazać - stopniowego wprowadzenia wspólnego, nowego języka - bośniackiego. Opublikowano m.in. w 1890 roku podręcznik regulujący zasady gramatyki (Gramatika bosanskog jezika). Niemniej w obliczu niechęci Serbów i Chorwatów do tej propozycji, władze okupacyjne wydały w 1907 roku decyzję o odstąpieniu od używania nazwy ,język bośniacki”. Skutkowało to np. tym, że wspomniany powyżej podręcznik wydano ponownie, bez jakichkolwiek zmian, poza korektą tytułu (Gramatika srpsko-hrvatskog jezika) ${ }^{40}$.

Ponownie kwestia językowa pojawiła się pod koniec lat 60 . XX wieku, kiedy na tym tle zaczął narastać konflikt między Zagrzebiem a Belgradem. Oficjalnie w republice przyjęto linię, iż język w Bośni i Hercegowinie jest odwzorowaniem ,jedności różnorodności”, a każdy mieszkaniec ma prawo do wyboru własnego wariantu. Aż do rozpadu Jugosławii skupiano się raczej na kodyfikacji języka, a nie jego statusie ${ }^{41}$. Sytuacja zmieniła już po przeprowadzonych jesienią 1990 roku wyborach do parlamentu republikańskiego, gdy nowo wybrani deputowani z dominujących partii nacjonalistycznych zaczęli domagać się publikacji aktów prawnych cyrylicą (Serbowie), w literackim języku chorwackim (Chorwaci) lub uwzględnienia w nich bośniacko-hercegowińskiej specyfiki (Muzułmanie) ${ }^{42}$.

Obowiązujące w Socjalistycznej Republice Bośni i Hercegowiny konstytucyjne rozwiązania dotyczące problematyki językowej nie będą raczej zaskoczeniem. W art. 216 republikańskiej ustawy zasadniczej z 1963 roku uznano serbsko-chorwacki za język,

\footnotetext{
38 J. Hlava č, Jezična politika i praksa u Europskoj Uniji, ,Jezik”, 2006, nr 3, s. 103.

39 J. Granić, Hrvatski kao 24. službeni jezik..., s. 333.

${ }^{40} \mathrm{~S}$. Halilović, Jezička stvarnost u Bosni i Hercegovini, s. 123.

${ }^{41}$ Ibidem, s. 124-125.

${ }^{42}$ I. L u č i ć, Bosna i Hercegovina od prvih izbora do međunarodnog priznanja, „Status”, 2007, nr 12, s. 191.
} 
w którym miano publikować wszelkie akty prawne. W 1974 roku jako język urzędowy wymieniono serbsko-chorwacki względnie chorwacko-serbski w wersji ijekawskiej ${ }^{43}$.

W latach 90. XX wieku, w trakcie wojny pojawił się problem z nazewnictwem języka, którym posługiwali się mieszkańcy Bośni i Hercegowiny. W obliczu oficjalnego rozpadu wspólnego języka należało wybrać którąś z opcji, a dotyczyło to szczególnie Muzułmanów, którzy w tych dramatycznych okolicznościach musieliby zdeklarować się, czy używają chorwackiego, czy też serbskiego. W lutym 1993 roku, gdy w warunkach wojennych Prezydium (kolegialna głowa państwa) ogłosiło Konstytucję Republiki Bośni i Hercegowiny, za język oficjalny uznano w niej serbsko-chorwacki względnie chorwacko-serbski w wersji ijekawskiej ${ }^{44}$. Jednak już w następnym roku sarajewskie Ministerstwo Szkolnictwa i Kultury podjęło decyzję, że jeden język będzie nosił trzy różne nazwy: bośniacki, serbski i chorwacki ${ }^{45}$.

Przed dość interesującym problemem językowym stanęli Serbowie mieszkający w Republice Serbskiej. Otóż chcąc również na lingwistycznym polu zbliżyć się do swoich rodaków w Serbii, musieliby porzucić wariant ijekawski, którym tradycyjnie posługiwali się od wieków, na rzecz ekawskiego ${ }^{46}$. Podjęte kroki motywowane były także chęcią odróżnienia się językowego od wrogów, czyli Chorwatów i Muzułmanów/Bośniaków. Polityczne i prawne dążenia władz Republiki Serbskiej nie przyniosły jednak spodziewanego rezultatu. Wprawdzie w 1993 roku samozwańczy parlament w Pale uchwalił kuriozalną ustawę, która nakazywała używanie wyłącznie ekawsztiny, ale po pięciu latach została ona uchylona ${ }^{47}$.

Dość szczególnym problemem, a właściwie wręcz punktem zapalnym, jest oficjalne nazewnictwo języka, którym posługują się Bośniacy (Bošnjaci). Oficjalnie używane jest określenie ,język bośniacki” (bosanski), co może sugerować, że jest to język wszystkich mieszkańców Bośni i Hercegowiny. Przeciwko takiej nazwie ostro protestowali i wciąż protestują Serbowie ${ }^{48}$ i Chorwaci ${ }^{49}$. Nie zmienia to jednak faktu, że w oficjalnym obiegu,

43 R. Dodig, Opaske o imenu jezika Bošnjaka, „Status”, 2004, nr 4, s.70.

44 Ibidem, s. 71.

${ }^{45}$ H. S u n d h a u s s e n, Od mita regije do „države na silu”: Metamorfoze u Bosni i Hercegovini, „Prilozi”, 2009, nr 38, s. 28.

${ }^{46}$ V. B. Sotirović, Bosanski jezik, Bošnjaci i Bosna i Hercegovina, http://www.nspm.rs (dostęp 15.05.2010 r.).

${ }^{47}$ R. B u gars k i, Portret jednog jezika, s. 41.

${ }^{48}$ W konstytucji Republiki Serbskiej nie wymienia się języków z nazwy, ale przyjęto w art. 8 iście salomonowe - jak nie bez złośliwości zauważa R. Bugarski - rozwiązanie, iż w tej jednostce językami urzędowymi są: ,jezik srpskog naroda, jezik bošnjačkog naroda i jezik hrvatskog naroda”. Zob.: R. B u g a r s k i, Portret jednog jezika, s. 36. Określenie jezik bošnjačkog naroda zostało zaskarżone do Sądu Konstytucyjnego, jednak w maju 2016 roku sędziowie uznali, że jest to neutralne sformułowanie, a każdy naród ma prawo nazywać swój język według własnego uznania. Nie ma zatem sprzeczności w sytuacji, w której Bošnjaci twierdzą, że posługują się językiem bośniackim (bosanskim). Zob.: 98. plenarna sjednica, http://ccbh.ba/novosti/sjednice/?id=cd90831c-d15d-46f8-b40f-ac9ef00383c8 (dostęp 27.09.2016 r.).

${ }^{49}$ S. Halilović, Jezička stvarnost u Bosni i Hercegovini, s. 132. Gdy w marcu 1994 roku pod presją Amerykanów formalizowano współpracę między Chorwatami i Bośniakami w postaci Federacji Bośni i Hercegowiny, podstawą był tekst konstytucji napisany po angielsku. W tłumaczeniu dla delegacji Bośniaków za języki urzędowe uznano bosanski i hrvatski, a dla delegacji chorwackiej - bošnjački i hrvatski. Również w pierwszych oficjalnych dokumentach obowiązywała wersja bošnjački, skorygowana jednak osobiście przez sekretarza Skupsztiny Konstytucyjnej Federacji Bośni i Hercegowiny - Bośniaka z pochodzenia - który stwierdził, że do wersji chorwackiej „,wkradł się błąd”. Zob. R. D o di g, Opaske o imenu..., s. 71. 
w tym także w konstytucjach na różnym poziomie administracyjnym, obowiązuje wersja bosanski jezik ${ }^{50}$.

Naukową premierę język bośniacki miał w 1996 roku, kiedy w Sarajewie ukazała się książka Pravopis bosanskog jezika, wydana latinica. Jej autor S. Halilović podjął próbę udowodnienia, że język ten różni się od chorwackiego i serbskiego ${ }^{51}$.

Jednym z symboli powojennych podziałów etnicznych i gwałtownego wzrostu nacjonalizmów stały się na obszarze Federacji Bośni i Hercegowiny szkoły znajdujące się w jednym budynku, ale podzielone na część chorwacką i bośniacką (dvije škole pod jednim krovom). W tym kuriozalnym systemie funkcjonuje obecnie ponad 50 placówek, w których realizuje się odmienne programy nauczania, w oparciu o różne podręczniki i języki wykładowe ${ }^{52}$.

Obecnie na mocy Konstytucji Bośni i Hercegowiny wszystkie trzy języki i oba alfabety mają równoprawny status. Przez pewien czas w Republice Serbskiej oraz Federacji Bośni i Hercegowiny obowiązywały w ustawach zasadniczych tych jednostek przepisy sprzeczne z konstytucją narzuconą w Dayton, jednak w kwietniu 2002 roku Wysoki Przedstawiciel Wspólnoty Międzynarodowej (OHR) skorzystał ze swoich uprawnień i wprowadził odpowiednie zmiany ${ }^{53}$. Trzeba jednak podkreślić, że nie doprowadziło to do sytuacji, w których wszystkie języki mają faktycznie taki sam status. Przykładem niech będzie ponownie Federacja - w pierwszych czterech klasach szkoły podstawowej dzieci mają minimalny kontakt z cyrylicą, co powoduje, iż ich biegłość czytania w tym alfabecie jest znacznie gorsza niż w alfabecie łacińskim ${ }^{54}$.

O tym, jak ważną politycznie rolę odgrywa problem nazewnictwa języka, niech świadczy spór, który miał miejsce w 2016 roku. W kwietniu na spotkanie w Mostarze, w którym uczestniczyło ok. 200 naukowców reprezentujących uczelnie powiązane z Bośniakami, ogłoszono Neretwańską deklarację o języku bośniackim. Starano się w niej dowieść wielowiekowej tradycji jego istnienia (począwszy od przełomu X i XI wieku). Ostro na deklarację zareagowało szczególnie chorwackie środowisko kulturalno-naukowe, protestując przeciwko zawłaszczaniu tradycji i kultury tylko przez jedną ze stron ${ }^{55}$.

Trafnie obecną sytuację językową w Bośni i Hercegowinie podsumowała H. Vajzović:

(...) w imię nacjonalistycznych standardów (trzy języki) ignoruje się istniejącą praktykę językową (jeden język), przy czym nierozwiązana kwestia języka służbowego jako środka wzajemnej komunikacji publicznej stwarza problemy w administracji, w szkolnictwie, mediach itp. ${ }^{56}$

${ }^{50}$ Szerzej na ten temat zob.: A. Ka la j d ž i j a, The Bosnian Language-Linguistic Entity and Sociolinguistic Continuity, „Bosnian Studies: Journal for Research of Bosnian Thought and Culture”, 2008, nr 1.

51 V. B. Sotirović, Bosanski jezik...

52 S. Halilović, Jezička stvarnost u Bosni i Hercegovini, s. 131.

${ }^{53}$ Ibidem, s. 127-128.

${ }^{54}$ N. Ibrahimović, Jezik $u$ osnovnoj školi, http://www.pulsdemokratije.net/index.php?id=1483\&l=bs (dostęp 21.04.2011 r.).

55 „Neretvanska deklaracija o bosanskom jeziku” je udar na temelje BiH, http://www.dnevnik.ba/revija/ kultura/neretvanska-deklaracija-o-bosanskom-jeziku-je-udar--na-temelje-bih (dostęp 27.09.2016 r.).

${ }_{56}$ H. Vaj zov ić, Jezik i nacionalni odnosi u Bosni i Hercegovini, „Godišnjak Fakulteta političkih nauka”, 2006, nr 1, s. 361. 


\section{Kwestia języka w Czarnogórze}

Najmłodszym językiem o statusie oficjalnego jest czarnogórski. Ten niewielki kraj otrzymał pierwszą konstytucję w 1905 roku, jednak wtedy kwestii języka oficjalnego w ogóle w niej nie poruszano. W następnej konstytucji, uchwalonej po II wojnie światowej w Czarnogórze, będącej już jedną z republik jugosłowiańskich, kwestię języka w zasadzie też pominięto, jedynie art. 113 określił język serbski jako ten, którym należy posługiwać się w postępowaniu przed sądami. Jednocześnie zagwarantowano obywatelom innych narodowości, nieznających serbskiego, prawo do skorzystania z usług tłumacza ${ }^{57}$.

W kolejnej republikańskiej ustawie zasadniczej za język urzędowy uznano serbsko-chorwacki, z zachowaniem prawa do posługiwania się własnym językiem dla ludności albańskiej. Wreszcie w ostatniej przed rozpadem Jugosławii konstytucji Republiki Czarnogóry z lutego 1974 roku za język urzędowy uznano serbsko-chorwacki w wersji ijekawskiej, z prawem do korzystania $\mathrm{z}$ obu alfabetów ${ }^{58}$.

Jeszcze w październiku 1992 roku, gdy przyjmowano konstytucję Republiki Czarnogóry, wchodzącej w skład Federacyjnej Republiki Jugosławii, w art. 9 za język urzędowy uznano serbski w wersji ijekawskiej, a oba alfabety miały mieć równorzędny status. W uchwalonej 19 października 2007 roku ustawie zasadniczej niepodległej Czarnogóry, w art. 13 nie zmienił się stosunek ustrojodawcy do alfabetu, natomiast pozycję języka urzędowego zyskał po raz pierwszy czarnogórski. Uznano jednocześnie, że także inne języki - serbski, chorwacki, bośniacki (bosanski) i albański - mogą być używane w kontaktach urzędowych. Ten mało precyzyjny zapis trzeba uznać za dość niefortunny, gdyż trudno jednoznacznie zdefiniować, czym się różni z punktu widzenia prawa język urzędowy (službeni) od języków w użyciu służbowym (u službenoj upotrebi $)^{59}$.

Spór o język(i) urzędowy(e) w Czarnogórze dotknął również systemu szkolnictwa. Po długich sporach politycznych w 2011 roku ówczesny premier Igor Lukšić podpisał $\mathrm{z}$ liderami opozycji porozumienie, które zostało następnie wprowadzone w życie w ustawie o kształceniu. Przewidziano w niej, że w miejsce dotychczasowego języka czarnogórskiego w szkołach będzie nauczany przedmiot pod skomplikowaną nazwą „Czarnogórski - serbski, bośniacki, chorwacki języki i literatura”. Jednak rozstrzygnięcie to zaskarżyła Matica crnogorska, a Sąd Konstytucyjny w lipcu 2013 roku wydał orzeczenie, w którym uznał przyjęte przepisy za sprzeczne z konstytucją, gdyż ograniczały one gwarantowaną w ustawie zasadniczej najważniejszą rolę języka czarnogórskiego ${ }^{60}$.

Jednym z największych paradoksów związanych ze standaryzacją języka czarnogórskiego jest to, że w procesie tym uczestniczyła grupa chorwackich lingwistów, co zresztą spotkało się z ostrą krytyką opinii publicznej ${ }^{61}$. Za kolejny zaskakujący fakt można uznać to, że według spisu powszechnego z 2011 roku język czarnogórski stanowi ojczysty dla mniejszej grupy obywateli niż formalnie mający status mniejszościowego język serbski (odpowiednio $37 \%$ do $43 \%)^{62}$.

${ }^{57}$ R. Glu š i c a, Jezička polityka u Crnoj Gori, s. 25.

58 Ibidem, s. 16.

59 M. Grč e vić, Suvremena jezična situacija u slavenskim zemljama, s. 156 i 159.

${ }^{60}$ Ustavi sud: Sporazum Lukšicia i opozicije o jeziku neustavan, http://www.vijesti.me/vijesti/ustavni-sudsporazum-luksicia-i-opozicije-o-jeziku-neustavan-141040 (dostęp 27.09.2016 r.).

${ }^{61}$ M. Grč e vić, Suvremena jezična situacija u slavenskim zemljama, s. 149.

${ }^{62}$ R. Bugars ki, Portret jednog jezika, s. 50. 


\section{Z perspektywy zagranicy}

Osobnym problemem, związanym z oficjalnym rozpadem serbsko-chorwackiej wspólnoty językowej, jest funkcjonowanie i akceptacja istnienia nowych języków na arenie międzynarodowej. Dla zdecydowanej większości badaczy czy polityków innych państw, zainteresowanych rozwojem sytuacji w regionie, obecne procesy językotwórcze mające miejsce w byłej Jugosławii są kompletnie niezrozumiałe i traktuje się je jako kolejny przejaw konfliktu.

Bardzo pragmatyczne rozwiązanie tego problemu znalazł amerykański Departament Stanu. Po przeprowadzeniu wizyt w 2009 roku przez jednego z urzędników ministerstwa w ambasadach USA znajdujących się w Chorwacji, Bośni i Hercegowinie, Serbii oraz Czarnogórze ogłoszono, iż obywatele wszędzie posługują się wprawdzie różnymi wariantami, ale jednak tym samym językiem. Takie podejście pozwoliło ograniczyć koszt kształcenia amerykańskich dyplomatów, gdyż zamiast czterech osobnych kursów językowych trwających po 44 tygodnie, ambasadorowie wysyłani w ten gorący politycznie region mogą przejść tylko jeden wspólny kurs, dający im uprawnienia do pełnienia misji we wszystkich wymienionych powyżej krajach. Natomiast występujące między wariantami różnice mogą zostać opanowane w ramach ćwiczeń konwersatoryjnych ${ }^{63}$.

Wśród instytucji międzynarodowych zaangażowanych na omawianym w niniejszej pracy obszarze jedną z najistotniejszych ról odgrywa Międzynarodowy Trybunał Karny dla byłej Jugosławii. Jego kierownictwo siłą rzeczy musiało przyjąć racjonalne stanowisko wobec skomplikowanej sytuacji językowej, żeby nie wpaść w pułapkę absurdu. Od samego początku funkcjonowania Trybunału przyjęto zasadę, że serbski, chorwacki $\mathrm{i}$ bośniacki to tak naprawdę jeden i ten sam język (określony mianem $\mathrm{B} / \mathrm{H} / \mathrm{S}$ ), więc nie ma konieczności tłumaczenia w trakcie posiedzeń np. z serbskiego na chorwacki. Tylko nieliczni z oskarżonych zakwestionowali to rozwiązanie, np. Vojislav Šešelj, zresztą bez reakcji ze strony sędziów ${ }^{64}$.

Pewien problem ze spuścizną po języku serbsko-chorwackim mają też zachodnie uniwersytety, gdzie za czasów komunistycznej Jugosławii prowadzono lektoraty w tym języku. Po rozpadzie wspólnoty przyjęto różne rozwiązania. I tak na niektórych uczelniach przyjęto rozwiązania częściowo mające swoje korzenie w nieistniejących już okolicznościach, np. w Hamburgu pozostawiono nazwę Serbo-Kroatisch, w Monachium oraz w Berlinie na Uniwersytecie Humboldta wprowadzono „łamaniec” Serbisch/Kroatisch, na Harvardzie wykłada się Croatian and Serbian, zaś w Wiedniu Bosnisch-Kroatisch-Serbisch $^{65}$. Równocześnie trwa swoista wojna podjazdowa o to, na jaki lektorat ewentualnie nastąpi zmiana na danym uniwersytecie. Władze Chorwacji wyłożyły znaczące środki na promocję swojego języka, w przeciwieństwie do Serbii, która wyraźnie oddała pod tym względem pole. Nawet rząd w Podgoricy podjął bardziej aktywne działania, doprowadzając m.in. do utworzenia na Uniwersytecie w Bari lektoratu języka czarnogórskiego ${ }^{66}$.

${ }^{63}$ S. Kord i ć, Jezična politika...

${ }^{64}$ J. Hl a v a č, Jezična politika i praksa..., s. 102.

${ }^{65}$ Ibidem, s. 101.

${ }^{66}$ M. Krk ić, Hrvatski, bosanski i crnogorski jezik istisnuće srpski sa katedri u Evropi, http://www.blic. rs z dnia 4.03.2012 (dostęp 26.06.2012 r.) 
W tym miejscu warto wskazać na jeszcze jeden, na razie czysto potencjalny problem, a mianowicie status nowych języków po ewentualnym wejściu Serbii, Czarnogóry oraz Bośni i Hercegowiny do Unii Europejskiej. Jest to temat, który budzi olbrzymie kontrowersje, choć obecnie prawdopodobieństwo jego wystąpienia jest niewielkie. Trudno sobie wyobrazić np. tłumaczenie symultaniczne z chorwackiego (który ma już status oficjalnego języka UE) na czarnogórski czy serbski. Z drugiej jednakże strony, deklaracje niektórych przedstawicieli instytucji unijnych są jednoznaczne i przewidują w przyszłości (po akcesji) utrzymanie dotychczasowej polityki UE wobec języków narodowych. Oznacza to nadanie miana języków oficjalnych także serbskiemu i czarnogórskiemu. Natomiast nierozwiązany pozostaje - nawet w sferze deklaratywnej - potencjalny problem z językami obowiązującymi w Bośni i Hercegowinie. Pytany o to rzecznik Komisji Europejskiej Dennis Abbott nie był w stanie udzielić odpowiedzi ${ }^{67}$. Można się tylko zastanawiać, czy $\mathrm{np}$. będzie wtedy w instytucjach unijnych obowiązywała podwójna wersja języka serbskiego - oparta na wariancie ekawskim dla przedstawicieli Serbii i na ijekawskim dla delegatów z Republiki Serbskiej w Bośni i Hercegowinie?

\section{Podsumowanie}

Opisane w niniejszym artykule rozwiązania, przyjęte po faktycznym rozpadzie serbsko-chorwackiej wspólnoty językowej, wskazują jednoznacznie na dominującą w tej kwestii rolę czynnika politycznego. Jak pisze J. Rapacka:

(...) niskość bariery językowej częściej bywała tu przekleństwem niż błogosławieństwem, nie tyle zbliżała, ile utrudniała rozgraniczenie, co stanowiło dodatkowy czynnik konfliktogenny, (...) zwiększało podatność na ideologiczne obłędy i polityczne machinacje ${ }^{68}$.

Warto przytoczyć także zdanie R. Szula:

Uznanie serbskiego, chorwackiego i bośniackiego za osobne języki znacząco obniżyło poprzeczkę, jaką mają spełniać warianty językowe, żeby uznać je za osobne języki, i w sposób dobitny wykazało, że status języka czy też wariantu językowego lub dialektu jest kwestią czysto polityczną ${ }^{69}$.

Z kwestią językową w byłej Jugosławii związane jest wiele paradoksów (oprócz tych, które już zostały opisane w tekście). Należy do nich m.in. to, że Chorwat mieszkający na północy kraju (np. w regionie Zagorje) będzie miał poważne kłopoty z porozumieniem się z rodakami z Hercegowiny czy Dalmacji (o wyspach na Adriatyku, gdzie silne są wpływy włoskie, nawet już nie wspominając), a każdy z nich będzie uparcie twierdzić, że posługuje się czystym językiem chorwackim ${ }^{70}$. Podobnych problemów komunikacyjnych nie będzie z kolei między przedstawicielami formalnie odrębnych narodów w Bośni i Hercegowinie, czyli między Chorwatem, Serbem i Bośniakiem.

${ }^{67}$ Koji će biti službeni jezik BiH u institucijama Europske unije? http://www.hrvatska-rijec.com/koji-cebiti-sluzbeni-jezik-bih-u-institucijama-europske-unije (dostęp 22.09.2016 r.).

${ }^{68}$ J. R a p a c k a, Śródziemnomorze - Europa Środkowa - Batkany..., s. 443.

${ }^{69}$ R. S zu 1, Język-naród - państwo..., s. 103.

${ }^{70}$ R. Bugars ki, Portret jednog jezika, s. 66. 
Przeprowadzone na początku obecnej dekady badania wykazały, że gdy grupę osób deklarujących, że posługują się językiem serbskim albo chorwackim, poproszono o przetłumaczenie kilku tekstów z języka angielskiego na ojczysty, końcowe wersje tekstu były niemal identyczne ${ }^{71}$. Równie interesująca jest informacja, że przez kilka lat na Uniwersytecie w Lublanie lektorem języka serbskiego był Chorwat ${ }^{72}$.

W niektórych przypadkach wyszukiwanie różnic językowych jest tak absurdalne, że autorzy tych prób narażają się na śmieszność. Do historii przeszedł serbski film Rane, który wyświetlany był w Chorwacji w wersji z chorwackimi napisami. W tym przypadku chęć użycia „czystego” chorwackiego sprawiła, że dla znacznej części chorwackiej publiczności bardziej zrozumiała była wersja oryginalna, czyli serbska, niż poprawne politycznie tłumaczenie na oficjalny język ojczysty ${ }^{73}$. Innym przykładem niech będą rozmowy pokojowe w Dayton, które zakończyły wojnę w Bośni i Hercegowinie - w ich trakcie były przygotowane trzy kabiny i tyle samo kanałów na potrzeby tłumaczenia symultanicznego $\mathrm{z}$ angielskiego na bośniacki, serbski i chorwacki, ale de facto tylko jedno wspólne tłumaczenie. I żadna z ultranacjonalistycznie nastawionych delegacji nie złożyła z tego powodu jakiegokolwiek zażalenia ${ }^{74}$.

Jednym z największych paradoksów, potwierdzających głównie polityczną, a nie lingwistyczną przyczynę zaistniałych podziałów, jest sytuacja mająca miejsce w szkołach kantonu Sarajewo. Rodzice, gdy tylko ich dzieci rozpoczynają naukę w pierwszej klasie, deklarują, w jakim języku mają się one uczyć - bośniackim, serbskim czy chorwackim (można także wybrać wszystkie trzy nazwy). Następnie wszyscy uczniowie - niezależnie od dokonanego przez rodziców wyboru - korzystają z tego samego podręcznika i realizują ten sam program kształcenia ${ }^{75}$.

Część autorów porównuje obecną sytuację językową na omawianym obszarze do tej, która miała miejsce w Austrii po zakończeniu II wojny światowej. Awersja do wszystkiego, co niemieckie, doprowadziła do sytuacji, że w szkołach nie używano oficjalnie określenia ,język niemiecki”, lecz ,język kształcenia”. Dopiero po siedmiu latach nastroje się uspokoiły i przywrócono poprzednią nazwę ${ }^{76}$. Patrząc jednak na dzisiejsze podejście do kwestii języka w Chorwacji, Serbii, Bośni i Hercegowinie oraz Czarnogórze, trudno oczekiwać, że podobna sytuacja nastąpi w przewidywalnej przyszłości. Raczej można spodziewać się dalszego wyszukiwania i pogłębiania różnic, w dużej mierze mających uzasadnienie wyłącznie polityczne. Słusznie, acz smutnie pisze M. Okuka:

(...) Serbowie, Chorwaci i Bośniacy nie tylko się nie lubią, lecz też zaprzeczają stanowczo, od niedawna nawet za pomocą wszelkich dostępnych środków, by mieli jakiś wspólny język. Nie ma już żadnej wartości to, co wspólne, lecz to, co różne. Różnice zaś trzeba znaleźć za wszelką cenę. Nawet siłą ${ }^{77}$.

${ }^{71}$ F. M. V. Kar a, A. Me th a džović, Standarizacija jezika, s. 68.

72 B. Đu r đević, Zabrinjavajuće stanje naših lektorata: Nemar gasi srpski jezik, http://www.novosti.rs, (dostęp 9.09.2016 r.).

73 R. B ugars ki, Portret jednog jezika, s. 75.

74 Provedba jednakopravnosti: Odluka o konstitutivnosti naroda u Bosni i Hercegovini, ,Izvještaj ICG-a za Balkan", nr 128, Sarajevo-Brussels, 16.04.2002, s. 21.

75 D. Dizdarević, Ko govori bosanski? http://pescanik.net/ko-govori-bosanski/ (dostęp 27.09.2016 r.).

76 S. Kordić, Jezična politika...

77 M. Okuka, Żegnaj, serbsko-chorwacki! 
Bez wątpienia język na obszarze byłej Jugosławii stał się środkiem kontynuacji głębokiej ideologicznej wrogości, a przestał być tym, czym powinien - czyli środkiem komunikacji.

\section{Bibliografia}

Monografie:

Barić E. i inni, Hrvatska gramatika, Zagreb 1997

Bugarski R., Portret jednog jezika, Beograd 2012

Rapacka J., Śródziemnomorze - Europa Środkowa - Bałkany. Studia z literatur południowosłowiańskich, Kraków 2002

Szul R., Język - naród - państwo. Język jako zjawisko polityczne, Warszawa 2009

Tripalo M., Hrvatsko proljeće, Zagreb 1990

Zacharias M. J., Komunizm - federacja - nacjonalizmy. System władzy w Jugosławii 1943-1991. Powstanie - przeksztatcenie - rozkład, Warszawa 2004

Artykuły

Borić B., Nova država - nova jezična politika, „Kroatologija”, 2014, nr 1

Dedović D., Do you speak BCS?, „Status”, 2004, nr 2

Dizdarević D., Ko govori bosanski? http://pescanik.net/ko-govori-bosanski/ (dostęp 27.09.2016 r.)

Dodig R., Opaske o imenu jezika Bošnjaka, „Status”, 2004, nr 4

Đurđević B., Zabrinjavajuće stanje naših lektorata: Nemar gasi srpski jezik, http://www.novosti. rs, (dostęp 9.09.2016 r.)

Glušica R., Jezička politika u Crnoj Gori, „Riječ. Nova serija”, 2009, nr 1

Granić J., Hrvatski kao 24. službeni jezik Europske unije, „Zbornik radova Filozovskog fakulteta u Splitu”, 2012, nr 5

Grčević M., Suvremena jezična situacija u slavenskim zemljama, [w:] Slavenski jezici u usporedbi z hrvatskim, red. D. Sesar, Zagreb 2011

Halilović S., Jezička stvarnost u Bosni i Hercegovini, „Socjolingwistyka”, 2014, XXVIII

Hlavač J., Jezična politika i praksa u Europskoj Uniji, „Jezik”, 2006, nr 3

Ibrahimović N., Jezik u osnovnoj školi, http://www.pulsdemokratije.net/index.php?id=1483\&l=bs (dostęp 21.04.2011 r.)

Kalajdžija A., The Bosnian Language - Linguistic Entity and Sociolinguistic Continuity, „Bosnian Studies: Journal for Research of Bosnian Thought and Culture", 2008, nr 1

Kara F. M. V., Methadžović A., Standarizacija jezika i stvaranje država u bivšoj Jugoslaviji, „Balkanija", 2013, nr 4

Kordić S., Jezična politika: prosvjećivati ili zamagljivati?, https://bib.irb.hr/datoteka/565627.JEZICNA_POLITIKA.PDF (dostęp 27.09.2016)

Kornhauser J., Konflikt kultur, http://pogranicze.sejny.pl/archiwum/krasnogruda/pismo/7/peryf/ kornhaus.htm (dostęp 25.07.2011)

Krkić M., Hrvatski, bosanski i crnogorski jezik istisnuće srpski sa katedri u Evropi, http://www.blic. rs z dnia 4.03.2012 (dostęp 26.06.2012 r.)

Krysieniel K., Język w stużbie polityki - przypadek współczesnej Chorwacji, [w:] Stowianie w Europie. Historia. Kultura. Język, red. K. Pietrzycka-Bohosiewicz, A. Wawrzyńczak, B. Gołąbek, Kraków 2008.

Lučić I., Bosna i Hercegovina od prvih izbora do međunarodnog priznanja, „Status”, 2007, nr 12

Oczkowa B., Wpływ polityki językowej w Jugosławii na normę języka chorwackiego, „Bulletin de la Société Polonaise de Linguistique”, 2002, LVIII 
Oczkowa B., Zagadnienia sporne w językoznawstwie chorwackim i serbskim po rozpadzie języka serbsko-chorwackiego, [w:] Przemiany w świadomości i kulturze duchowej narodów Jugostawii po 1991 roku, red. J. Kornhauser, Kraków 1999

Okuka M., Żegnaj, serbsko-chorwacki!, http://pogranicze.sejny.p1/archiwum/krasnogruda/pismo/7/ peryf/okuka.htm (dostęp 27.04.2011)

Sotirović V. B., Bosanski jezik, Bošnjaci i Bosna i Hercegovina, http://www.nspm.rs (dostęp 15.05.2010 r.)

Sundhaussen H., Od mita regije do „, države na silu”: Metamorfoze u Bosni i Hercegovini, „Prilozi”, 2009, nr 38

Vajzović H., Jezik i nacionalni odnosi u Bosni i Hercegovini, „Godišnjak Fakulteta političkih nauka", 2006, nr 1,

Raporty

Provedba jednakopravnosti: Odluka o konstitutivnosti naroda u Bosni i Hercegovini, „Izvještaj ICG-a za Balkan”, nr 128, Sarajevo-Brussels, 16.04.2002

Krzysztof Krysieniel

When a Common (?) Language Divides ...

The Political and Legal Consequences of the Breakdown of the Serbo-Croatian Language (or Croatian-Serbian)

Summary

The disintegration of Yugoslavia in the last decade of the twentieth century has resulted in the breakdown of many of the ties that have grown to a greater or lesser extent during the period of its existence. Apart from the economic, political or social ties, one must not forget about a certain linguistic community, which has been developing since the nineteenth century, including Serbs and Croats, as well as present-day people of Montenegro and Bosnia and Herzegovina.

There are many myths and misconceptions surrounding it that will continue to cause heated discussions and debates. This happens regardless whether Serbo-Croatian is treated as a real existence or merely as an artificial creation, a result of the policies of the respective countries.

The current standardization processes (including legal), which at all costs demonstrate the differences between Croatian, Serbian, Montenegrin and Bosnian, are the result of politicization of the language. It happens even though people using these different (?) languages can understand each other with no difficulty (same as in e.g. English in the US and Great Britain or German in Germany and Austria).

Keywords: Serbo-Croatian language, Serbian language, Croatian language, Bosnian language, Balkan dialects. 